\title{
Toxicity Studies on Flour Produced from Unpeeled Green Plantains
}

Abdul R. Rahman, C. M. Berrocal, J. R. Cruz-Cay, and J. D. Rivera-Anaya ${ }^{1}$

\section{INTRODUCTION}

It has been known for some time that many local farmers have served plantain peels to their livestock and hogs as a regular feed for many years, yet no ill or toxic effects were observed. But a thorough search of the literature failed to reveal studies of these practices.

An economical method for the production of flours from entire plantains, including the skin, has been developed by Abdul R. Rahman $(1)^{2}$ of the Food Technology Laboratory of the Agricultural Experiment Station of the University of Puerto Rico. Since this flour was developed for human consumption, an experiment was conducted to determine the possibility of toxic effects on chicks, thus determining its suitability for food.

\section{MATERIALS AND PROCEDURES}

Twenty-two 12-day-old chicks were brought from the Lajas Substation. They were divided into two equal groups. Each group was weighed as one unit and placed in a clean cage with adequate space and water supply. One group was served commercial chickenfeed purchased from the local market and the other received a mixture of $1 / 3$ commercial chickenfeed and $2 / 3$ plantain flour. The commercial feed was added as a protein supplement to the flour. Each 3 to 4 days the cages were cleaned, the water was changed, feed was added, and the chicks were weighed. Frequent observations were made also on each bird to detect physical defects, injuries, or sickness. The experiment continued until the chicks were large enough for the commercial market as fryers. Four chicks of each group were taken at random during the experiment and slaughtered.

\section{RESULTS AND DISCUSSION}

The results shown in tables 1 and 2 indicate that the chicks fed on a mixture of plantain flour and commercial chickenfeed were lighter in weight

1 Associate Food Technologist, Food Technology Laboratory; Assistant Bacteriologist, Department of Animal Husbandry; Research Assistant, Food Technology Laboratory; and Veterinarian, Department of Animal Husbandry; respectively, Agricultural Experiment Station, University of Puerto Rico, Río Piedras, P.R. The authors wish to thank M. Rojas-Daporta of the Lajas Substation for furnishing the chicks. Thanks are also due to the Food Technology Laboratory staff members who participated in the organoleptic appraisals of the chicken meats.

3 Rahman, A.R., Economical chemical pretreatment method for the production of flour from green plantains, J. Agr. Univ. P.R. 47 (1) 1-10, 1963. 
than the others. However, this might have been caused by the low protein content of the plantain flour, which was 2.8 percent.

The gross and the dressed weights of 4 fryers raised on commercial feed for 45 days were 8.6 and 6.25 pounds, respectively; similar figures for fryers raised on $1 / 3$ commercial feed and $2 / 3$ plantain flour were 7.6 and 5 pounds.

The gross weights and the dressed weights of 3 fryers raised on commercial feed for 75 days were $\mathbf{1 1 . 0}$ and $\mathbf{9 . 0}$ pounds, respectively; similar figures for fryers raised on $1 / 3$ commercial feed and $2 / 3$ plantain flour were 7.5 and 6.0 pounds.

TABLE 1. Weight of 11 chicks served commercial chickenfeed compared with a similar number served a mixture of $1 / 3$ commercial feed and $2 / 3$ plantain four for 45 days

\begin{tabular}{|c|c|c|c|c|c|c|c|c|c|c|c|c|c|}
\hline Feed & \multicolumn{13}{|c|}{ Weight in pounds at 3- to 4 -day intervals } \\
\hline $\begin{array}{l}\text { Commercial } \\
\text { chickenfeed }\end{array}$ & 5.16 .9 & \begin{tabular}{|l|l|l|}
7.68 .48 .8 \\
\end{tabular} & 10.8 & 11.2 & 12.1 & 13.8 & 14.7 & 15.4 & 18.4 & 19.0 & 20.6 & $20.8 \mid$ & 23.6 \\
\hline $\begin{array}{l}\text { 3/3 commer- } \\
\text { cial plus 2/3 } \\
\text { plantain } \\
\text { flour }\end{array}$ & 5.14 .0 & 5.77 .48 .0 & 9.4 & 9.8 & 10.8 & 12.5 & 13.1 & 13.0 & 16.0 & 16.6 & $\mid 16.6$ & 17.0 & 18.2 \\
\hline
\end{tabular}

TABLE 2.-Weights of 7 chicks served commercial chickenfeed compared with a similar number raised on a mixture of $1 / 3$ commercial $+2 / 3$ plantain flour for 75 days

\begin{tabular}{l|c|c|c|c}
\hline \multicolumn{1}{c|}{ Feed } & \multicolumn{4}{|c}{ Weight in pounds at 3- to 4-day intervals } \\
\cline { 2 - 4 } Commercial chickenfeed & 16.2 & 16.6 & 18.8 & 20.0 \\
$\begin{array}{l}1 / 3 \text { commercial plus 3/3 plantain } \\
\text { flour }\end{array}$ & 12.8 & 12.6 & 12.6 & 14.0 \\
\hline
\end{tabular}

Postmortem examinations indicated that birds served a mixture of $1 / 3$ commercial chickenfeed plus $2 / 3$ plantain flour were smaller, lighter, and possessed thinner breasts than the other group. However, the meat and internal organs appeared normal, although the gizzard lining peeled in shreds. No ulcers or lesions could be observed on the internal wall of the gizzards.

The organoleptic appraisal tests showed no difference in color or flavor between the two groups as indicated by 11 judges. No mortality occurred during the whole experiment.

\section{SUMMARY}

Two groups of 11 chicks each were used in this experiment. One group was fed commercial chickenfeed, whereas the other was served a mixture 
of $1 / 3$ commercial feed plus $2 / 3$ plantain flour produced from the entire fruit, for a period of 45 days. The experiment continued in the same manner with the groups reduced to seven chicks each, for a period of 75 days.

The results follow:

1. The group served commercial chickenfeed only was heavier and fatter than the other group.

2. During postmortem observations no ill or toxic effects could be observed in either group.

3. No mortality occurred during the whole experiment.

4. Organoleptic tests revealed no differences in the color or flavor of the meat of both groups.

\section{RESUMEN}

Dos grupos de 11 pollos, cada uno integraron este experimento. A un grupo de los pollos se le suplió alimento comercial para aves y al otro una mezcla de $1 / 3$ parte de alimento comercial y $2 / 3$ partes de harina de plátano preparada de la fruta, incluyendo la cáscara, por un período de 45 días. El experimento continuó de la misma manera reduciendo los grupos a 7 pollos cada uno por un período de 75 días.

Los resultados del experimento fueron los siguientes:

1. Los animales que recibieron alimento comercial para aves lograron mejor peso y engorde.

2. Al ser sacrificados no se observó enfermedad alguna ni efecto tóxico de la harina del plátano en ninguno de los dos grupos de animales que la consumieron.

3. No hubo mortandad en los pollos mientras duró el experimento.

4. Las pruebas organolépticas no revelaron diferencias en el color y sabor de la carne de ambos grupos.

\section{ERRATUM}

An error of omission occurred in the July 1962 issue. The correction is incorporated in the following:

Page 221, line 4 should read 